UDC 613.8: 614.1

DOI: 10.21668/health.risk/2019.1.14.eng

\title{
RISK FACTORS THAT CAUSE DEVELOPMENT AND PROGRESSION OF DEGENERATIVE AND DYSTROPHIC DISEASES IN THE SPINAL COLUMN AS PER RESULTS OBTAINED DURING SCREENING TESTS ON PEOPLE LIVING IN SAINT PETERSBURG
}

\author{
M.V. Avdeeva ${ }^{1}$, Yu.A. Kreneva ${ }^{2}$, V.P. Panov ${ }^{1,2}$, V.N. Filatov ${ }^{1}$, \\ A.V. Mel'tser ${ }^{1}$, L.A. Karasaeva ${ }^{1}$
}

${ }^{1}$ I.I. Mechnikov's North-Western State Medical University of the RF Public Healthcare Ministry, 47 Piskarevskiy av., Saint Petersburg, 195067, Russian Federation

${ }^{2}$ Municipal polyclinic No.14, 35 the 2nd Murinskiy av, Saint Petersburg, 194021, Russian Federation.

According to the WHO, degenerative-dystrophic diseases in the spinal column occur in $80 \%$ of overall population and account for up to $90 \%$ of all the chronic diseases cases. Data and methods. To assess prevalence of degenerative-dystrophic diseases in the spinal column among people living in Saint Petersburg, we performed screening tests on 5,797 people (their average age was $56.52 \pm 18.39$; body mass index was $26.78 \pm 15.42 \mathrm{~kg} / \mathrm{m}^{2}$; spine length was $443.30 \pm 39.85 \mathrm{~mm})$. Men accounted for $25.6 \%$ among the examined people $(n=1,482)$; women, for $74.4 \%(n=4,315)$. All the participants underwent a complex examination; they were questioned (we applied a specially designed questionnaire made up of 124 questions); their spinal columns (3 sections in them) were x-rayed; we also accomplished computer optical topography with "DIERS Formetric 4D" device (Germany); the last stage was a consultation by a neurologist.

The prevalence of degenerative-dystrophic diseases in the spinal column amounts to $71.5 \%$ among people living in Saint Petersburg. We detected functional disorders in the spinal column in all the examined patients. Degenerativedystrophic diseases in the spinal column can progress not only due to functional disorders in it but also under influence exerted by social and economic factors such as social status $(b=0.43 ; p<0.01)$, age $(b=0.18 ; p<0.01)$, occupational peculiarities $(b=0.17 ; p<0.01)$, limited financial opportunities to preserve health $(b=0,15 ; p<0,01)$. Personal and behavioral factors also exert their impacts on risks of degenerative-dystrophic diseases; such factors are rare appeal for medical aid $(b=0.18$; $p<0.01)$, poor literacy of the population $(b=0,17 ; p<0,01)$, self-treatment $(b=0.14 ; p<0.01)$. Poor quality of medical health also causes elevated risks of degenerative-dystrophic diseases $(b=0.18 ; p<0.01)$.

Most risk factors that influence development and progression of degenerative-dystrophic diseases in the spinal column are manageable (behavioral-personal factors, socioeconomic factors, quality and availability of medical aid). Timely examination, treatment, and rehabilitation of patients suffering from degenerative-dystrophic diseases are important spheres where quality and availability of primary medical and sanitary care can be improved.

Key words: prevalence of degenerative-dystrophic diseases in the spinal column, risk factors, osteochondrosis risk, age-related changes in the spinal column.

(c) Avdeeva M.V., Kreneva Yu.A., Panov V.P., Filatov V.N., Mel'tser A.V., Karasaeva L.A., 2019

Marina V. Avdeeva - Doctor of Medicine, Professor at the Department of Public Health, Economics and Health Management (e-mail: Lensk69@mail.ru; tel.: + 7 (812) 543-02-32; ORCID: http://orcid.org/0000-0002-4334-5434).

Julia A. Kreneva - Head of the Rehabilitation Department (e-mail: krenewa@yandex.ru; tel.: 7 (812) 550-24-67; ORCID: https://orcid.org/0000-0002-4926-9639).

Viktor P. Panov - Doctor of Medicine, Professor at the Department of Public Health, Economics and Health Management (e-mail:p1-4@yandex.ru; tel.: 7 (812) 550-24-67; ORCID: https://orcid.org/0000-0002-0894-6656).

Vladimir N. Filatov - Doctor of Medicine, Professor, Head of the Department of Public Health, Economics and Health Management (e-mail: Vladimir.Filatov@szgmu.ru; tel.: +7 (812) 543-02-32; ORCID: http://orcid.org/0000-0003-1017-9975).

Alexander V. Mel'tser - Doctor of Medicine, Professor, Vice-Rector responsible for the development of regional health care and preventive medical care (e-mail: rectorat@szgmu.ru; tel.: + 7 (812) 303-50-00; ORCID: https://orcid.org/ 0000-0003-4186-457X).

Lyudmila A. Karasaeva - Doctor of Medicine, Professor at theDepartment of Public Health, Economics and Health Management (e-mail: ludkaras@yandex.ru; tel.: +7(812) 543-02-32; ORCID: https://orcid.org/0000-0001-5621-0240). 
Introduction. According to the WHO, degenerative and dystrophic spine diseases (DDSD) occur in $80 \%$ population and account for up to $90 \%$ of all the chronic diseases $[1,2,3,4,5]$. Screening x-ray examinations reveal that the first signs of DDSD, namely a decrease in intervertebral spaces, occur as early as at the age of 6 ; and when a person is 12 he or she already has subchondral bone sclerosis [6]. Each fifth person in the world who is older than 30 suffers from DDSD [1, 7]. Pathologies in the musculoskeletal system occupy the first place in the overall morbidity structure among people who are older than $50[8,9]$. Some data imply that DDSD prevalence and disorders in the spinal column functioning amount to 122 per 1,000 adults. And at the same time 80$100 \%$ people occasionally suffer from spondylogenic pains in the spine $[10,11]$, but only about $40 \%$ of them apply for medical aid [12]. DDSD with spondylogenic pain syndrome as a reason to visit a doctor occupies the second place after respiratory diseases and it holds the third place among reasons for admission to hospital [13, 14, 15, 16]. A number of such admissions due to spondylogenic pain syndrome has been growing over the recent years [17]. About $10 \%$ of all the patients suffering from DDSD become disabled, and the figure is substantially higher among patients who have undergone a surgery and it reaches $70.3 \%$ [18]. Therefore, DDSD prevalence can be considered a pandemic and it is a grave medical and socioeconomic problem in the developed countries [2, 19]. But still, timely detection, treatment, and rehabilitation is extremely important for improving life quality and medical and social forecasts for patients suffering from DDSD.

Our research goal was to examine prevalence and risk factors that cause degenerative and dystrophic spine diseases (DDSD) in people living in Saint Petersburg as per results of a complex screening examination.

Data and methods. To assess DDSD prevalence among people living in Saint Pe- tersburg, we performed a screening examination of 5,797 people (their average age was equal to $56.52 \pm 18.39$; body mass index was $26.78 \pm 15.42 \mathrm{~kg} / \mathrm{m}^{2}$; spine length was $443.30 \pm$ $\pm 39.85 \mathrm{~mm}) .25 .6 \%$ of the examined people were males $(n=1,482)$, and $74.4 \%$ females $(n=4,315)$. People were chosen for examination via a simple random sampling among people who lived on a territory where medical services were provided by a municipal polyclinic. There was an age-related criterion for people to be included into the sampling as they had to be 18 years old or older. Anyone who refused to take part in the examination was not included into the sampling.

All the participants underwent a complex examination: they were questioned (we applied a specially designed questionnaire that contained 124 questions); their spinal columns (all three sections) were x-rayed; we performed computer optical topography with "DIERS Formetric 4D" device (Germany) as per a conventional procedure [20,21]; all the people included in the sampling were examined by a neurologist. Computer optical topography allowed to assess biomechanics of the spinal column and pelvis as per the following parameters: spine length in $\mathrm{mm}$ (C7-DMmm), spine curve in degrees $\left(\mathrm{C} 7-\mathrm{DM}^{\circ}\right)$, vertical deviation in $\mathrm{mm}$ (VP-DMmm), pelvis tilt in degrees (DL-DR ${ }^{\circ}$ ), pelvis tilt in $\mathrm{mm}$ (DL-DRmm), pelvis rotation in degrees (DL-DR ${ }^{\circ}$ ), pelvis curve in degrees, kyphosis angle in degrees (ICT-ITL ${ }^{\circ}$ ), lumbar lordosis angle in degrees (ITL-ILS ${ }^{\circ}$ ), rotation of surface in degrees $\left(\mathrm{RMS}^{\circ}\right)$, lateral deviation in $\mathrm{mm}$ (VPDMmm).

All the obtained data were statistically analyzed with "Statistica 10.0" applied software package. Statistical data are given as a simple mean and standard deviation $(\mathrm{M} \pm \sigma)$ or a percent $(\%)$. When qualitative signs were compared, we calculated $\chi^{2}$ criterion. We also performed multiple regression with stepwise elimination and determination of regression quotient $b$. Discrepancies were considered to be statistically significant at $p<0.05$. 
Results. X-ray revealed DDSD signs in $71.5 \%$ of the examined people. $15.4 \%$ of them suffered from pains in the thoracic spine when they were examined; $14.7 \%$, from pains in the cervical spine; and $41.3 \%$, from pains in the lumbar spine (Figure 1).

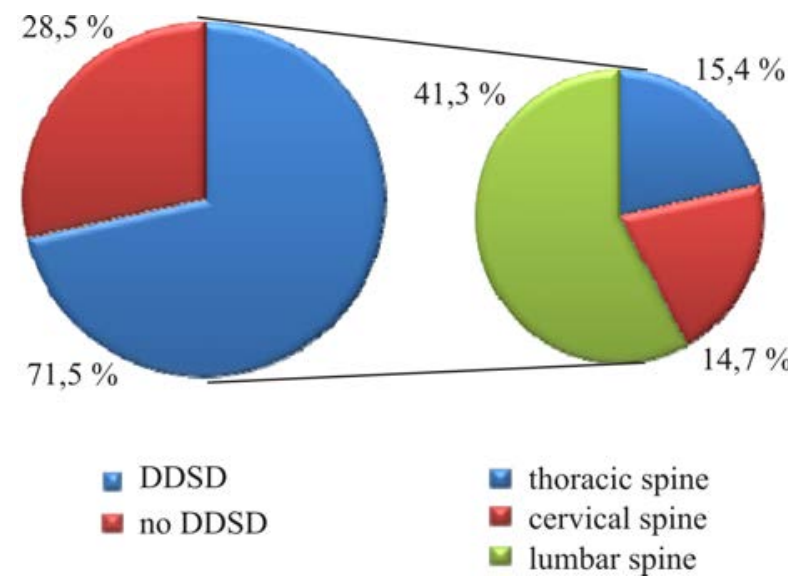

Figure 1. DDSD prevalence among people living in Saint Petersburg as per screening examination data

Computer optical topography revealed that $100 \%$ examined people had functional disorders in the spinal column. As we can see from the data presented in Table 1, such functional disorder as a change in lumbar lordosis angle was the most frequent $(81.2 \%)$, values of the parameter being either higher than the reference one $(50.3 \%)$ or lower than it $(30.9 \%)$. Besides, the examination revealed such functional disorders in the spinal column as deviations from the standard spine curve $(75.0 \%)$ and kyphosis angle $(67.9 \%)$.

Regression analysis revealed that signs of spondylogenic pain syndrome occurred not only under influence exerted by functional state of the spine (spine length, kyphosis angle, spine curve, rotation of surface, lordosis angle, and pelvis curve) but also by biological factors. Thus, data presented in Table 2 indicate that spondylogenic pain syndrome can occur due to constitutive peculiarities of a patient (body mass index $(b=0.09 ; \mathrm{p}<0.05)$ and age $(b=0.04 ; p<0.05)$. In particular, patients who didn't have any pain syndrome turned out to be younger $(51.67 \pm 18.92$ and $55.28 \pm 17.28 ; \mathrm{p}<0.01)$ and had lower body mass index $(25.74 \pm 13.11$ and $26.79 \pm 7.04$; $\mathrm{p}<0.01)$ than those who complained of a chronic pain syndrome.

Regression analysis allowed to spot out basic DDSD-associated factors. They are all stratified into three categories: 1) socioeconomic factors (social status, age, limited financial means to preserve health etc.);

Table 1

Prevalence of functional disorders in the spinal column as per results obtained vi screening computer optical topography

\begin{tabular}{|c|c|c|c|c|c|c|}
\hline \multirow[t]{2}{*}{ Parameters } & \multicolumn{2}{|c|}{$\begin{array}{l}\text { No functional } \\
\text { disorders }\end{array}$} & \multicolumn{2}{|c|}{$\begin{array}{l}\text { Functional disorders } \\
\text { are detected }\end{array}$} & \multirow[t]{2}{*}{$\chi^{2}$} & \multirow[t]{2}{*}{$\mathrm{p}$} \\
\hline & $\%$ & Abs. & $\%$ & Abs. & & \\
\hline Spine curve in degrees $\left(\mathrm{C}^{2}-\mathrm{DM}^{\circ}\right)$ & $25.0 \%$ & 1,449 & 75.0 & 4,348 & 50.0 & $<0.01$ \\
\hline Vertical deviation in mm (VP-DMmm) & $51.4 \%$ & 2,979 & $48.6 \%$ & 2,818 & 0.18 & $>0.05$ \\
\hline Pelvis tilt in degrees $\left(\mathrm{DL}^{-\mathrm{DR}^{\circ}}{ }^{\circ}\right.$ & $95.0 \%$ & 5,509 & $5.0 \%$ & 288 & 162.0 & $<0.01$ \\
\hline Pelvis tilt in mm (DL-DRmm) & $54.3 \%$ & 3,150 & $45.7 \%$ & 2,647 & 1.28 & $>0.05$ \\
\hline Pelvis rotation in degrees $\left(\mathrm{DL}-\mathrm{DR}^{\circ}\right.$ ) & $52.9 \%$ & 3,066 & $47.1 \%$ & 2,731 & 0.72 & $>0.05$ \\
\hline Pelvis curve in degrees & $50.4 \%$ & 2,922 & $49.6 \%$ & 2,875 & 0.02 & $>0.05$ \\
\hline Kyphosis angle in degrees $\left(\right.$ ICT-ITL $^{\circ}$ ) & $32.1 \%$ & 1,861 & $67.9 \%$ & 3,936 & 24.5 & $<0.01$ \\
\hline $\begin{array}{l}\text { Lumbar lordosis angle in degrees } \\
\left(\text { ITL-ILS }{ }^{\circ} \text { ) }\right.\end{array}$ & $18.8 \%$ & 1,087 & $81.2 \%$ & 4,710 & 79.4 & $<0.01$ \\
\hline Rotation of surface in degrees $\left(\mathrm{RMS}^{\circ}\right)$ & $57.9 \%$ & 3,359 & $42.1 \%$ & 5,326 & 4.5 & $<0.05$ \\
\hline Lateral deviation in degrees (VPDMmm) & $85.2 \%$ & 4,937 & $14.8 \%$ & 860 & 100.83 & $<0.01$ \\
\hline
\end{tabular}


Functional changes in the spine that are associated with a risk of DDSD occurrence and development and spondylogenic pain syndrome

(multiple regression with stepwise elimination)

\begin{tabular}{|c|c|c|c|}
\hline $\begin{array}{l}\text { Risk factor associated with pain syndrome } \\
\text { occurrence }\end{array}$ & $\begin{array}{l}\text { Regression } \\
\text { quotient } b\end{array}$ & $\begin{array}{l}\text { Standard } \\
\text { error } \mathrm{m}\end{array}$ & $\mathrm{p}$ \\
\hline Kyphosis angle in degrees (ICT-ITL $^{\circ}$ ) & 0.14 & 0.02 & $<0.001$ \\
\hline Spine curve in degrees $\left(\mathrm{C}^{2}-\mathrm{DM}^{\circ}\right)$ & 0.12 & 0.02 & $<0.01$ \\
\hline Body mass index $\left(\mathrm{kg} / \mathrm{m}^{2}\right)$ & 0.09 & 0.01 & $<0.01$ \\
\hline Spine length in $\mathrm{mm}$ (C7-DMmm) & 0.06 & 0.02 & $<0.01$ \\
\hline Rotation of surface in degrees $\left(\mathrm{RMS}^{\circ}\right)$ & 0.05 & 0.02 & $<0.01$ \\
\hline Lordosis angle in degrees (ITL-ILS $^{\circ}$ ) & 0.05 & 0.02 & $<0.01$ \\
\hline Age (years) & 0.04 & 0.02 & $<0.05$ \\
\hline Pelvis curve in degrees & 0.04 & 0.02 & $<0.05$ \\
\hline
\end{tabular}

2) behavioral factors and factors related to an individual life style (poor medical and preventive activity, self-treatment, occupational peculiarities, rare appeal for medical aid etc.); 3) defects related to medical aid provision (poor quality of medical aid, absence of regular medical check-ups etc.) (Table 3).

Socioeconomic risk factors that cause DDSD occurrence and development. According to our regression analysis results, this category includes the following risk factors: social status $(b=0.43 ; p<0.001)$; age $(b=0.18 ; p<0001)$; occupation (labor) $(b=0.17$; $\mathrm{p}<0.01)$; limited financial means to preserve health and to get access to physical and health-improving activities $(b=0.15 ; \mathrm{p}<0.05)$; limited access to medications, preventive and health-improving activities that are necessary to preserve and improve health $(b=0.14 ; p<0.05)$. We analyzed impacts exerted by a social status on DDSD occurrence frequency and revealed that employed people tended to suffer from spondylogenic pain syndrome more frequently than unemployed people or students $(56.5 \%$ and $41.2 \% ; 2.3 \%$; $\left.\chi^{2}=10.2 ; \mathrm{p}<0.01\right)$. We detected that most examined patients had occupations that involved intellectual labor $(79.6 \%)$; those related to physical labor were much less frequent $(20.4 \%)$. And here we noted that people who dealt with intellectual labor tended to suffer from pains in the spine more frequently than those who dealt with physical labor (accordingly: $67.6 \%$ and $32.4 \%$; $\left.\chi^{2}=24.5 ; \mathrm{p}<0.001\right)$. Patients who dealt with predominantly intellectual labor and were employed in different spheres complained of spondylogenic pain syndrome with different frequency; we detected the following figures for different occupations: $27.0 \%$ for workers employed in education, medicine or people with creative labor; $20.3 \%$ for workers employed in retail and service sector; and $20.3 \%$ for workers occupying managerial positions or employed in economic and financial sphere $\left(\chi^{2}=12.2 ; \mathrm{p}<0.001\right)$. We should also note that only $30.1 \%$ patients stated all medications were available to them and they actively used such medications to treat DDSD. Only 19.8\% patients told they had sufficient financial means to get access to all necessary health-improving activity and DDSD treatment.

Personal and behavioral risk factors that cause DDSD occurrence and development. According to our regression analysis results, this category includes the following risk factors: patients not attending preventive medical check-ups $(b=0.20 ; p<0.01)$; rare appeal for medical aid $(b=0.18 ; p<0.01)$; appeal for medical aid to a wrong specialist when health deteriorates $(b=0.18 ; p<0.01)$; low literacy and absence of any knowledge on basic principles that explain how to treat and to prevent the 
Basic risk factors that cause DDSD occurrence and development in people living in Saint Petersburg (multiple regression with stepwise elimination)

\begin{tabular}{|l|c|c|c|}
\hline Factors causing development of the disease & $\begin{array}{c}\text { Regression } \\
\text { quotient b }\end{array}$ & $\begin{array}{c}\text { Standard } \\
\text { error } \mathrm{m}\end{array}$ & $\mathrm{p}$ \\
\hline \multicolumn{3}{|c|}{ Socioeconomic risk factors } \\
\hline Social status (students, employed, unemployed) & 0.43 & 0.10 & $<0.001$ \\
\hline Age & 0.18 & 0.06 & $<0.01$ \\
\hline Occupation and labor (physical or intellectual labor) & 0.17 & 0.03 & $<0.01$ \\
\hline $\begin{array}{l}\text { Limited financial means to preserve health and get access } \\
\text { to medical and health-improving procedures that are nec- } \\
\text { essary to preserve and improve health }\end{array}$ & 0.15 & 0.05 & $<0.05$ \\
\hline $\begin{array}{l}\text { Limited access to medications, preventive and health- } \\
\text { improving activities that are necessary to preserve and } \\
\text { improve health }\end{array}$ & 0.14 & 0.06 & $<0.05$ \\
\hline \multicolumn{4}{|c|}{ Personal and behavioral risk factors } \\
\hline Rare appeal for medical aid
\end{tabular}

disease $(b=0.17 ; p<0.05)$; proneness to selftreatment $(b=0.14 ; p<0.01)$; poor medical and preventive activity of patients $(b=0.12$; $\mathrm{p}<0.01$ ). In particular, only $30.5 \%$ patients suffering from spondylogenic pain syndrome knew what medications they had to take to prevent and treat DDSD. Only 3.1\% patients had groups consultations on how to prevent DDSD; however, most questioned patients $(84.0 \%)$ didn't think it was necessary.

Quality and availability of medical aid as a risk factor that causes DDSD occurrence and development. According to our regression analysis results, this category includes the following risk factors: poor availability of primary healthcare $(b=0.18 ; p<0.01)$; poor quality of preventive consultations $(b=0.15 ; p<0.01)$; rare prescription of medical, health-improving, and recovering procedures by doctors in a polyclinic $(b=0.14 ; p<0.05)$; rare and irregular interaction $\mathrm{n}$ between a doctor and a patient concerning the disease $(b=0.14 ; p<0.05)$; absence of regular medical check-ups in case of DDSD $(b=0.11 ; p<0.05)$.

Discussion. Available literature data indicate that in Russia there have been only few 
sporadic examinations on DDSD prevalence among population groups different as per age and sex $[15,16]$. Thus, there was a screening examination performed on 452 people, and its results revealed 56\% DDSD prevalence among adult population [3]. But at the same time, our screening research performed on 5,797 people revealed that DDSD could occur in $71.5 \%$ people older than 18 .

There was an epidemiologic examination with more than 46,000 questioned participants living in various European countries and Israel; its results revealed that 24\% respondents complained of spine pains with different localization. $18 \%$ adults living in Europe and Israel had pains in their lumbar spine, and 8\%, pains in their neck [22]. Epidemiologic research based on questioning was also performed in Russia $(n=3,998)$; the results revealed high prevalence of spondylogenic pain syndrome $(67.7 \%)$, including cases with temporary disability (36.7\%) [23]. There is an opinion that DDSD usually don't have any symptoms or any other subjective signs, and they are most frequently diagnosed only due to x-ray examinations [24]. In our research functional disorders were diagnosed in $100 \%$ participants $(n=5,797)$, and spondylogenic pain syndrome with variable intensity occurred in $71.5 \%$ examined patients. High prevalence of spondylogenic pain syndrome was also detected in other research $[12,25]$. According to the obtained data, pains in lumbar spine occurred most frequently $(41.3 \%)$ and it was well in line with data obtained in other research [26]. Spondylogenic pain syndrome turned out to more frequently occur in employed patients and it was not so frequent in unemployed ones and students $(56.5 \%$ and $41.2 \% ; 2.3 \%$; $\left.\chi^{2}=10.2 ; \mathrm{p}<0.01\right)$. Other research also revealed that pains in the spine more frequently occurred among employable people and it proved the issue was medically and socially significant [22]. Our research revealed that people occupied with intellectual labor complained of pains in the spine most frequently $(79.6 \%)$. On the contrary, other research indicated that DDSD and spondylogenic pain syndrome more frequently occurred in people occupied with physical labor [27].

The research detected primary factors that influenced DDSD occurrence and development; these factors were divided into 1) socioeconomic ones (social status, age, limited financial means to preserve health etc.); 2) behavioral factors and lifestylerelated factors (low medical and preventive activity, self-treatment, occupational peculiarities, rare appeal for medical aid, etc.); 3) factors related to poor quality and availability of medical aid (primary healthcare not being available, poor quality of preventive consulting provided for patients, absence of regular medical check-ups etc.). Most these factors are quite manageable; for example, proneness to self-treatment, rare appeal for medical aid, low literacy of population as regards the disease treatment and prevention, high body mass index, poor quality of medical aid, etc. There is other research that also revealed poor quality of medical aid provided for patients with DDSD. In particular, results obtained during research on medical aid quality revealed that it was proper only in $14 \%$ cases when patients with DDSD were treated. And most errors made by doctors were caused by non-optimal use of public healthcare resources when a disease was diagnosed; due to it, further errors occurred in the process of treating a patient [28]. And at the same time, timely examination and recovery therapy make for efficient treatment of spondylogenic pain syndrome as well as for significantly improved functional state of the spinal column in patients suffering from DDSD [1].

Vertebral pathology has its peculiarities and one of them is that doctors with variable specializations participate in its treatment, namely neurologists, physical therapists, therapists, rheumatologists, reflex therapists, manual therapists, homeopaths, and anesthesiologists [29]. Our research revealed that DDSD development is often influenced by 
patients appealing for medical aid to a wrong specialist $(b=0.18 ; p<0.05)$ thus putting themselves at risk that qualified medical aid would not be provided for them in due time.

Given the fact that socioeconomic situation in the society is improving gradually, activities aimed at providing social support for citizens are being enhanced and public healthcare is granted more financial resources, we can also consider such factors as limited financial means to preserve health and get access to medical and health-improving procedures $(b=0.14 ; p<0.05)$; and limited access to medications necessary for DDSD treatment $(b=0.14 ; p<0.05)$ to be quite manageable. Consequently, only age $(b=0.18$; $\mathrm{p}<0.05)$ can be considered unmanageable among all the analyzed risk factors that cause DDSD occurrence and development. Large multi-centered foreign research also revealed that age was a significant risk factor that caused DDSD development [2, 30]. Therefore, if we want to eliminate high morbidity with DDSD, we need a complex approach that involves socioeconomic growth, better quality and availability of medical aid, changes in ordinary lifestyle, and adjustment of manageable risk factors at individual level. Analysis of DDSD and spondylogenic pain syndrome prevalence among people living in Saint Petersburg allowed us to estimate how significant the problem was; the data which we obtained in our research can be applied for determining population demand for medical rehabilitation.

\section{Conclusions}

1. According to the results obtained in the screening examination, DDSD prevalence amounts to $71.5 \%$ among people living in Saint Petersburg. All the examined patients have functional disorders in the spinal column, the most frequent ones being lumbar lordotic angle $(81.2 \%)$, spine curve angle $(75.0 \%)$, and kyphosis angle $(67.9 \%)$ deviating from the physiological standard.

2. Patients suffering from DDSD most frequently complain of pains in the lumbar spine $(41.3 \%)$; pains in the thoracic spine $(15.4 \%)$, and the cervical spine $(14.7 \%)$ are less frequent. When spondylogenic pain syndrome occurs in a patient with DDSD, it can be related not only to functional disorders in the spinal column, but also to influences exerted by certain biological factors (age or high body mass index).

3. Occupational peculiarities also produce their effects on DDSD and spondylogenic pain syndrome $(b=0.17 ; p<0.01)$. In particular, this pathology more frequently occurs in people who are predominantly occupied with intellectual labor, and not with physical one $(67.6 \%$ and $\left.32.4 \% ; \chi^{2}=24.5 ; \mathrm{p}<0.001\right)$. DDSD and spondylogenic pain syndrome are more frequently detected in people employed in education and medicine, or people with creative occupations; they are less frequently detected in people employed in retail or service sector as well as in workers who occupy managerial positions or are employed in the sphere of economics and finance $\left(\chi^{2}=12.2 ; \mathrm{p}<0.001\right)$.

4. Most risk factors that influence DDSD occurrence and development are quite manageable: such factors are socioeconomic ones; personal and behavioral factors; quality and availability of medical aid. Timely examination, treatment and rehabilitation of patients with DDSD is a significant component in improving quality and availability of primary healthcare.

Funding. The research was not granted any sponsor support.

Conflict of interests. The authors state there is no any conflict of interests. 


\section{References}

1. Kreneva Yu.A., Panov V.P., Avdeeva M.V., Bogomolova K.A. Vosstanovitel'nyi potentsial kompleksnykh reabilitatsionnykh meropriyatii pri okazanii pervichnoi mediko-sanitarnoi pomoshchi bol'nym so spondilogennym bolevym sindromom [Restorative potential of complex rehabilitation in the primary health care provision for patients with degenerative disc diseases]. Profilakticheskaya $i$ klinicheskaya meditsina, 2018, no. 2, pp. 76-82 (in Russian).

2. Armbrecht G., Felsenberg D., Ganswindt M., Lunt M., Kaptoge S.K., Abendroth K. [et al.]. European Vertebral Osteoporosis Study and European Prospective Osteoporosis Study Groups. Degenerative inter-vertebral disc disease osteochondrosis intervertebralis in Europe: prevalence, geographic variation and radiological correlates in men and women aged 50 and over. Rheumatology (Oxford), 2017, no. 7, pp. 1189-1199.

3. Armbrecht G., Felsenberg D., Ganswindt M., Lunt M., Kaptoge S.K., Abendroth K. European Vertebral Osteoporosis Study and European Prospective Osteoporosis Study Groups. Vertebral Scheuermann's disease in Europe: prevalence, geographic variation and radiological correlates in men and women aged 50 and over. Osteoporos International, 2015, no. 10, pp. 2509-2519.

4. Muraki S., Oka H., Akune T., Mabuchi A., En-Yo Y., Yoshida M. et al. Prevalence of radiographic lumbar spondylosis and its association with low back pain in elderly subjects of populationbased cohorts: the ROAD study. Annals of the Rheumatic Diseases, 2009, no. 9, pp. 1401-1406.

5. Goode A.P., Marshall S.W., Renner J.B., Carey T.S., Kraus V.B., Irwin D.E. et al. Lumbar spine radiographic features and demographic, clinical, and radiographic knee, hip, and hand osteoarthritis. Arthritis Care and Research (Hoboken), 2012, no. 10, pp. 1536-1544.

6. Orel A.M. Vozrastnye aspekty epidemiologii degenerativno-distroficheskikh izmenenii mezhpozvonkovykh diskov po dannym sistemnogo analiza rentgenogramm pozvonochnika [Age aspects epidemiology of degenerative dystrophic changes intervertebral disks on data system analysis spine roentgenograms]. Meditsinskaya vizualizatsiya, 2010, no. 5, pp. 113-121 (in Russian).

7. Tae-Won J., Yeon-Soon A., Junsu B., Jong-In L., Kun-Hyung K., Youngki K.[et al.]. Lumbar intervertebral disc degeneration and related factors in Korean firefighters. BMJ Open, 2016, no. 6, pp. e011587.

8. Vyalkov A.I., Gusev E.I., Zborovskii A.B., Nasonova V.A. Osnovnye zadachi Mezhdunarodnoi Dekady (the bone and joint decade 2000-2010) v sovershenstvovanii bor'by s naibolee rasprostranennymi zabolevaniyami oporno-dvigatel'nogo apparata $\mathrm{v}$ Rossii [Basic objectives of international «The bone and joint decade 2000-2010» in improvement of the measures against the most prevalent diseases of locomotor system in Russia]. Nauchno-prakticheskaya revmatologiya, 2001, no. 2, pp. 4-8 (in Russian).

9. Delitto A., George S.Z., Dillen L.V., Whitman J.M., Sowa G.A., Shekelle P. [et al.]. Low Back Pain: Clinical Practice Guidelines Linked to the International Classification of Functioning, Disability, and Health from the Orthopaedic Section of the American Physical Therapy Association. Journal of Orthopaedic \& Sports Physical Therapy, 2012, no. 4, pp. 1-57.

10. Hoy D., Brooks P., Blyth F., Buchbinder R. The Epidemiology of low back pain. Best Practice and Research: Clinical Rheumatology, 2010, no. 6, pp. 769-781.

11. Khetagurova Z.V., Gabaraeva L.N., Totrov I.N., Albegova Z.A. Struktura i chastota bolei v nizhnei chasti spiny sredi vzroslogo naseleniya [Structure and frequency of pains in the lower part of the back among adult population]. Nauchno-prakticheskaya revmatologiya, 2006, no. 2, pp. 118-119 (in Russian).

12. Tyurnikov V.M. Degenerativno-distroficheskie porazheniya pozvonochnika: diagnostika, klinika i lechenie [Degenerative-dystrophic lesions of the spine: diagnosis, clinic and treatment]. Russkii meditsinskii zhurnal. Nevrologiya Psikhiatriya, 2008, no. 26, pp. 17-46 (in Russian).

13. Povoroznyuk V.V. Bol' v nizhnei chasti spiny. Rasprostranennost', prichiny, mekhanizmy razvitiya i osobennosti diagnostiki [Pain in the lower back. Prevalence, causes, developmental mechanisms and diagnostic features]. Bol', sustavy, pozvonochnik, 2011, no. 1, pp. 13-22 (in Russian). 
14. Penina G.O. Ob"ektivizatsiya nevrologicheskikh proyavlenii osteokhondroza poyasnichnogo otdela pozvonochnika u zhitelei severnykh territorii [Objectification of neurological manifestations of osteochondrosis of the lumbar spine among residents of northern territories]. Bulletin of the International Scientific Surgical Association, 2006, no. 3, pp. 37-38 (in Russian).

15. Vyshlova I.A., Karpov S.M., Starodubtsev A.I. Vertebrogennye bolevye sindromy poyasnichnogo urovnya: epidemiologiya, klinicheskie proyavleniya [Low back pain syndrome: epidemiology and clinical manifestations]. Meditsinskii vestnik Severnogo Kavkaza, 2016, no. 4, pp. 586-587 (in Russian).

16. Osipov A.V., Chechenin A.G., Kolbasko A.V., Onishchenko A.L. Rasprostranennost' nevrologicheskikh proyavlenii poyasnichnogo osteokhondroza u teleutov korennogo sel'skogo naseleniya Kemerovskoi oblasti [Prevalence OF neurological manifestation lumbar osteochondrosis in primary population of Kemerovo region - teleuts]. Acta Biomedica Scientifica, 2013, no. 90, pp. 44-47 (in Russian).

17. Povzun A.S., Kisel'gof O.G., Povzun K.A., Alimov R.R., Miroshnichenko A.G. Osteokhondroz: analiz gospitalizatsii patsientov s ostrym bolevym sindromom [Osteochondrosis: analysis of hospitalization of patients with acute pain]. Skoraya meditsinskaya pomoshch', 2014, no. 4, pp. 61-64 (in Russian).

18. Oleinik A.D., Zarudskii A.V., Firsova N.V. Rannyaya diagnostika razlichnykh form poyasnichnogo osteokhondroza [Early diagnostics of different forms of the lumbar osteochondrosis]. Statsionarozameshchayushchie tekhnologii: Ambulatornaya khirurgiya, 2007, no. 4, pp. 158-159 (in Russian).

19. Podchufarova E.V., Razumov D.V. Rol' bolevogo povedeniya v formirovanii invalidizatsii u patsientov s khronicheskoi bol'yu v spine [The role of painful behavior in the formation of disability in patients with chronic pain in the back]. Rossiiskii meditsinskii zhurnal, 2010, no. 3, pp. 11-18 (in Russian).

20. Harzmann H.. Stellenwert der Videorasterstereografie als schulärztliche Screeningmethode von skoliotischen Fehlhaltungen und strukturellen Skoliosen. Dissertation. München, LudwigMaximilians-Universität Publ., Medizinische Fakultät, 2000.

21. Schröder J. Stiller T. Mattes, K. Referenzdaten in der Wirbelsäulenformanalyse. Manuelle Medizin, 2011, no. 49, pp. 161-166.

22. Siddall P.J., Cousins M.J., Otte A., Griesing T., Chambers R., Murphy T.K. Pregabalin in central neuropathic pain associated with spinal cord injury: a placebo-controlled trial. Neurology, 2006, no. 10, pp. 1792-1800.

23. Dorohov A.V., Dac L.S., Men'shikova L.V. Rasprostranennost' bolei v spine sredi podrostkov i vzroslogo naseleniya g. Irkutska [The prevalence of back pain among adolescents and adults of Irkutsk]. Sibirskii meditsinskii zhurnal (Irkutsk), 2007, no. 7, pp. 111-113 (in Russian).

24. Ibragimov A., Avezova G.S. Meditsinskaya i sotsial'naya znachimost' problemy poyasnichnogo osteokhondroza [Medical and social significance of the problem of lumbar osteochondrosis]. European Association of pedagogues and psychologists «Science», 2017, pp. 151-153 (in Russian).

25. Adambaev Z.I., Kilichev I.A. Vostrebovannost' statsionarzameshchayushchikh ambulatoriev v lechenii i reabilitatsii bol'nykh s degenerativnymi zabolevaniyami pozvonochnika v Uzbekistane [The demand stationer of ambulatories in the treatment of and rehabilitation of patients with degenerative diseases of the spine in Uzbekistan]. Problemy sovremennoi nauki i obrazovaniya, 2016, no. 5, pp. 231-236 (in Russian).

26. Vieira L.A., Dos Santos A.A., Peluso C., Barbosa C.P., Bianco B., Rodrigues L.M.R. Influence of lifestyle characteristics and VDR polymorphisms as risk factors for intervertebral disc degeneration: a case-control study. European Journal of Medical Research, 2018, no 23, pp. 11.

27. Safina A.G., Stepuk N.V., Raimkulova H.B., Raimkulova K.B., Zarpullaev Zh.Sh., Bhat N.A Kliniko-epidemiologicheskie pokazateli dorsalgii [Clinical and epidemiological indicators of dorsalgia]. Vestnik KazNMU, 2012, no. 3, pp. 59-62 (in Russian). 
28. Analiz kachestva meditsinskoi pomoshchi patsientam s degenerativno-distroficheskimi zabolevaniyami pozvonochnika v Sankt-Peterburge [Analysis of the quality of care for patients with degenerative-dystrophic diseases of the spine in St. Petersburg]. Tyumenskii meditsinskii zhurnal, 2012, no. 2, pp. 28-29 (in Russian).

29. Krut'ko A.V., Bedoreva I.Yu., Shalygina L.S., Kislitsyna L.V. Sovershenstvovanie organizatsii meditsinskoi pomoshchi patsientam s degenerativno-distroficheskimi zabolevaniyami poyasnichnogo otdela pozvonochnika [Improving the organization of medical care for patients with degenerative-dystrophic diseases of the lumbar spine]. Problemy sotsial'noi gigieny, zdravookhraneniya $i$ istorii meditsiny, 2012, no. 2, pp. 26-31 (in Russian).

30. Koji A., Tomomi Y., Nozomu I., Akinobu N., Akihiro S. Risk factors for lumbar intervertebral disc height narrowing: a population-based longitudinal study in the elderly. BMC Musculoskelet Disorders, 2015, no. 16, 344 p.

Avdeeva M.V., Kreneva Yu.A., Panov V.P., Filatov V.N., Mel'tser A.V., Karasaeva L.A. Risk factors that cause development and progression of degenerative and dystrophic diseases in the spinal column as per results obtained during screening tests on people living in saint petersburg. Health Risk Analysis, 2019, no. 1, pp. 125-134. DOI: 10.21668/health.risk/2019.1.14.eng

Received: 30.01 .2019

Accepted: 24.02.2019

Published: 30.03 .2019 